\title{
POST-DISASTER HOUSING RECONSTRUCTION: THE IMPACT OF RESOURCING IN POST- CYCLONE SIDR AND AILA IN BANGLADESH
}

\section{INTRODUCTION}

Natural disasters are a recurrent and rampant problem, and they occur more often in the contemporary world, posing great risk to lives and properties of affected population. In 2015, more than 23,744 people were killed and approximately 59,7667 people were rendered homeless worldwide, and in 2016, 3,451 people were killed and 60,571 were rendered homeless due to natural disasters (Centre for Research on the Epidemiology of Disasters, 2017). The average reported losses rose from around US\$ 50 billion a year in 1980 to almost US\$ 200 billion a year in the past decades totalling US\$ 3.8 trillion from 1980 to 2012 (The World Bank, 2013a).

Bangladesh is prone to natural disasters. It is ranked first in the world in terms of vulnerability, sixth globally in terms of human exposure to floods and cyclones, and third out of 76 countries in terms exposure to tsunami (GFDDR and ECHO, 2016). Due to natural disasters, especially cyclones, the housing sector in Bangladesh has been heavily affected. Most of the reconstructed houses are fragile (Da Silva and Batchelo, 2010; Hakim, 2009; Nadiruzzaman and Paul, 2013) and disaster victims still live in embankments, in one case up to seven years after the cyclone (Kabir, 2009; Paul and Routray, 2013)

The international community including the World Bank, the UNDP, the IFRC, local governments and national and international non-governmental organisations have extended their efforts to reduce the vulnerability of the affected people through provision of humanitarian assistance to disaster victims. Despite their efforts, and the core principles outlined by UN HABITAT for durable, permanent and cyclone resilient houses; post-disaster reconstruction projects remain unsatisfactory (Da Silva and Batchelo, 2010; Freeman, 2004; Kulatunga et al., 2014; Lin Moe et al., 2007; Lloyd-Jones, 2006) and the people affected by cyclones often live in embankments and polders (Haider and Ahmed, 2014; Kulatunga et al., 2014; Nadiruzzaman and Paul, 2013; Paul and Routray, 2013). Efforts often fail to deliver their stated objectives in terms of timely and effective responses to the needs and demands of the disaster-affected population (Duyne Barenstein and Leemann, 2012; Kulatunga et al., 2014; Lyons, 2009) ( Samah et al. 2014). The failure of post-disaster reconstruction projects is associated with the following factors: lack of coordination among participant organisations (Hidayat, 2013), lack of available resources (Chang et al., 2012), delays in project implementations (Nazara and Resosudarmo, 2007), corruption (The World Bank, 2013a), poor quality of reconstructed houses (Ahmed and Charlesworth, 2015; Silva and Batchelor, 2010), lack of community participation (Davidson et al., 2007), and ineffective design (Ika et al., 2012). 
This paper aims to evaluate the effectiveness of resourcing in reconstructing houses for the coastal people of Bangladesh affected by cyclone disasters. It also identifies the key challenges of post-disaster housing reconstruction and key success factors of resourcing. Finally, this paper develops a dynamic theoretical framework that enables key stakeholders and international practitioners to rebuild cyclone resilient houses.

\section{THEORETICAL BACKGROUND}

This paper draws on theories and literature relating to resourcing for post-disaster housing reconstruction in order to illuminate the factors that affect post-disaster housing reconstruction, exploring key success factors of resourcing for post-disaster housing reconstruction and explore possible ways to rebuild cyclone resilient houses for the people affected by cyclone disasters. Although the study of disaster is a growing field, the research on resourcing for post disaster housing reconstruction is relatively limited. Specifically, to the knowledge of this researcher, no primary investigation has been carried out on the effectiveness of resourcing for post-disaster housing reconstruction projects in Bangladesh and elsewhere. Therefore, in order to explore the effectiveness of resourcing in post disaster housing reconstruction, this study has drawn from existing theories of Access to Resource Model (ARM), and Sustainable and Resilient Community Framework (SRCF).

The literature suggests that post-disaster housing reconstruction projects in the developing countries are at an unsatisfactory level as they fail to meet the need of poor communities trying to recover from disasters (Da Silva and Batchelo, 2010; Lloyd-Jones, 2006). Post-disaster housing reconstruction is one of the least successful sectors in terms of implementation (Barenstein and Isaac, 2007) because reconstructed houses are typically very fragile and risky for people affected by cyclones (Akter and Mallick, 2013; Kabir, 2009; Lin Moe et al., 2007). The people affected by cyclones often live in embankments and polders for years after disaster (Haider and Ahmed, 2014; Kabir, 2009; Paul and Routray, 2013) and government's public spending decision making processes for post disaster housing reconstruction projects are generally affected by other considerations rather than the needs of affected people (Karim and Noy, 2015).

Scholars in this research area have deployed a wide range of arguments about resourcing and its implications for post disaster housing reconstruction. For example, Freeman (2004) and (Lloyd-Jones, 2006) argued that post disaster housing reconstruction resources normally go into the hands of the social and political elites and the aid as a humanitarian assistance lie paralysed in the account of governments and NGOs. On the other hand, (Chang et al., 2010, 2012; Singh and Wilkinson, 2008) reported that post disaster reconstruction projects generally suffer from resource bottlenecks. However, these authors did not identify the underlying reasons of resource bottlenecks; instead they identified the factors that affect resource availability. In contrast, (Burnell, 2010) argued that the commodification of aid especially for housing reconstruction 
embodies cultural symbolism, social power dynamics, and political affiliations and can have negative effects on long-term and sustainable reconstruction.

\subsection{Access to Resource Model (ARM)}

The Access to Resource Model deals with the amount of access that people must have as capabilities, assets, and livelihood opportunities which will enable them to reduce their vulnerability and avoid disaster. Generally, access involves the ability of an individual, family, group, class or community to use resources which are directly required to secure a livelihood in normal, pre-disaster times, and their ability to adapt to new and threatening situations. Access to such resources is always based on social and economic relations, including the social relations of production, gender, ethnicity, status and age, thus implying that rights and obligations are not distributed equally among all people.

\subsection{Sustainable and Resilient Community Framework (SRCF)}

Sustainable and resilient community framework was introduced by Tobin in 1999. The underlying philosophy of this framework is based on assessing the resilience of disaster-affected communities. Thus Tobin, (1999) integrated three separate models into one framework in order to show how sustainable and resilient communities could be created. These are i) the mitigation model, ii) the recovery model, and iii) the structural cognitive model. The figure 1 depicts a dynamic system and each model consists of integrated factors which are employed in assessing the resilience of disaster affected societies. However, the ultimate goal of this model is to attain community sustainability and resilience in the face of prevailing natural disasters.

\subsection{Conceptual framework}

The conceptual framework of this study was developed from the synthesis of litertaure review, approaches and theories relating to resourcing and its implication in post-disaster housing reconstruction. Concepts and factors such as unsafe conditions and disasters, coping and adapting capacity developement, stakeholders involvement, income geenrating activities, and restoration of livelihoods can play a significant role in building up the coping and adapting capacity of disaster affected people. Therefore the model shows how post-disaster housing recovery and reconstruction progress through some critical stages. 


\section{INSERT FIGURE 1 HERE}

There are seven critical stages of the conceptual framework, and each stage represents sharply inter-related ideas, thoughts and a distinct process that leads into the progression of housing recovery and reconstruction. The framework highlights the stages, challenges and processes required for disaster victims to move from the state of vulnerability and unsafe conditions precipitated by natural disasters towards safety and security. As figure 1 shows, resourcing is central because it plays a central role for recovery of livelihoods and shelters in post-disaster chaotic environment. This framework also illuminate the risk and vulenrability of households who often depend on political and social processes that allocate assets and income and other resources based on patronage and personal influence. Social systems create conditions in which hazards have different impacts on different groups of people. The framework also shows that peoples' vulnerability is related to, and aggravted by their location in disaster-prone areas. Where there is low vulnerability, the impact of disasters is significantly reduced (Lyons, 2009). This paper argues that vulnerable people suffer more from disasters because they have lack the resources to cope with and withstand disasters. Further, it explores the impact of income levels and income generating activities on coping strategies and access to resources.

\section{THE EMPIRICAL CONTEXT: POST-DISASTER HOUSING RECONSTRUCTION IN BANGLADESH}

Bangladesh, with a population of $154,695,368$, is a country that is particularly prone to natural disasters: $26 \%$ of the population are affected by cyclones and $70 \%$ live in flood-prone regions, and $31.5 \%$ of the population live below the national poverty line (United Nations Development Programme, 2015). Housing reconstruction is a key element of post disaster recovery initiatives in developing countries (Ahmed, (Bakeri and Bakar, 2011). However, post-disaster housing-reconstruction in Bangladesh is not satisfactory; rather, the coastal population affected by disasters suffer from uninhabitable houses many years after the cyclone disasters (Mallick et al., 2017). In 1960, the old Pakistani government (at present Bangladesh) undertook an initiative to construct 2000 units of two-storey buildings as coastal community centres and single-storey buildings as sub-coastal community centres. After the liberation war of 1971, the devastating cyclone of 1970 resulted in the loss of some 300,000 lives and it led into the construction of designated cyclone-shelters for the first time. Between 1972 and 1979, some 238 shelters were constructed in various locations in the coastal belt of Bangladesh (Mallick et al., 2017). The coastal areas of Bangladesh consist of 16 districts and it had a population of 38.2 million in 2009 with 2,583 usable cyclone shelters (Da Silva and Batchelo, 2010; Minar et al., 2013; Nadiruzzaman and Paul, 2013). These cyclone shelters are inadequate as they can accommodate only 7.3\% of the total coastal population(Da Silva and Batchelo, 2010; Hakim, 2009). 
In the case of Cyclone Sidr in 2007 and Aila in 2009, the Bangladesh government initiated an early recovery project to provide temporary shelter for the people affected by cyclones (de Bangladesh, 2008). Many people affected by cyclones need temporary shelters until permanent housing is constructed. Considering this issue, Bangladesh government provided one time housing assistance of $5000 \mathrm{BD}$ taka to some 100,000 families whose houses were totally destroyed in the affected areas, along with 13,000 bundles of corrugated iron sheets, 13,406 tents, and 15,000 plastic sheets to provide transitional shelters (de Bangladesh, 2008; Nadiruzzaman and Paul, 2013). Nadiruzzaman and Paul (2013) argued that although temporary housing provided by Government and other NGOs help the victims to solve their housing problems for the time being, it was insufficient, and many beneficiaries did not use the assistance for its intended purpose; rather, they sold donated house-construction items and bought other essential commodities. Therefore, their demands of housing reconstructions remained unmet.

Bangladesh is a developing country that depends mainly on external aid to cope with the additional expenditure which is required for post disaster housing reconstruction. It was the 24th largest recipient of official humanitarian aid in 2012 at US\$87 million, and from the year 2000 to March of 2013, it received $\$ 678 \mathrm{~m}$ in humanitarian aid for flood and cyclone related disasters (Bank, 2014). Despite the humanitarian assistance provided by the international community, post-disaster housing reconstruction in Bangladesh is not at satisfactory level; rather, disaster survivors still live in embankments and polders. In order to improve the quality and standard of current PDHR projects, Bangladesh government introduced the slogan of 'build back better' approach to rebuild safer homes for the people affected by cyclones. The key components of the 'build back better' approach is to improve the construction quality of destroyed and damaged houses in Cyclone Sidr and Aila affected areas which incorporates with the wind resistant houses developed after the 1997 cyclone in the Chittagong area (IFRC, 2010).

Besides UN HABITAT, many national and international NGOs (BRAC, Concern Worldwide, World Vision, and Muslim Aid) give preference to Core Shelter Programme (CSP) which can withstand strong cyclones. However, the constructed houses as a principle of core shelter fail to meet the standards of cost-effective analysis (Hakim, 2009; Nadiruzzaman and Paul, 2013; Silva and Batchelor, 2010). In spite of their efforts, governments and NGOs constructed houses did not meet the public expectations(Nadiruzzaman and Paul, 2013).

A few studies have been conducted on PDHR in Bangladesh but most of these have focused on different approaches of PDHR ((Ahmed, 2011; Ahmed and Charlesworth, 2015; Da Silva and Batchelo, 2010), investigating the Build Back Better approach in government housing reconstruction projects (Nadiruzzaman and Paul, 2013) and sustainability of assisted shelter (Hakim, 2009). Studies on resourcing for post-disaster 
housing reconstructing are quite limited. Little is known about resourcing and its implications on postdisaster housing reconstruction (Chang et al., 2012) and existing studies provide little empirical evidence about resourcing and its effectiveness in PDHR projects and other key success factors associated with postdisaster housing reconstruction. This study fills this gap in knowledge by evaluating the effectiveness of resourcing in PDHR projects.

\section{METHODOLOGY AND DATA SOURCES}

\subsection{Hypothesis}

The hypotheses examined in this study are summarized below:

\section{INSERT TABLE 1 HERE}

\subsection{Study Area}

In order to achieve the aim and objectives of this research, two coastal districts were selected in Bangladesh. Multi-stage sampling was employed to select two out of the four unions in Shyamnagar thana in Sathkhira District, and two out of the four unions in Bagerhat districts. Gabura and Padma Pukur from Sathkhira, and Sharan Khola and South khali unions from Bagerhat have been selected because those unions are the worst affected areas (Ahmed and Charlesworth, 2015; Haider and Ahmed, 2014; Kulatunga et al., 2014).

\subsection{Sampling and data collection}

This study employs both quantitative and qualitative methods to collect the necessary data to realise the aim and objectives of the study, as well as to ensure the reliability and validity of the study. To evaluate the effectiveness of resourcing in post-disaster housing reconstruction, the following parameters were used: rate of housing recovery, livelihood recovery, vulnerability reduction, poverty reduction; quality of reconstructed houses and beneficiary's satisfaction. Among the villagers affected by cyclones, questionnaire survey was administered. The study employs a multi-stage purposive sampling, based on the districts and villages most affected by, and most vulnerable to, the cyclones. Prior to the field study, initial contacts were established with community and political leaders in Stakhira and Bagerhat districts in Bangladesh. From these two districts, four Unions of Villages were selected: Southkhali with a population of 24,980 and Sharankola with a population of 119,084 both from Bagerhat district; and Gabura with a population of 32,417 and Padmapukur with a population of 22,858 from Stakhira district. These figures are based on the latest official census (Nadiruzzaman and Paul, 2013). From these unions of villages, initial lists of affected villagers were then drawn from the local government offices. From this list, 380 names were randomly drawn, 95 each from each of the four unions of villages. Care was taken to ensure that the chosen names represent a good spread around age, gender, education and profession. Out of the 380 questionnaires, 285 completed ones- 
representing $75 \%$ of the total number- were deemed usable for data analysis. Semi-structured interviews were also undertaken with local government officials, and from national and international stakeholders including UNDP and OXFAM. Twenty-three respondents were invited for interview but three respondents did not turn up at the agreed time. Therefore, the interview of 20 respondents was completed, a response rate of $86 \%$.

\subsection{Variables and measures}

Below is a quick overview of the main variables used in this study and how they have been measured:

Access to resources: This is the main dependent variable, and it was measured using a multi-dimensional construct in which binary (yes/no) responses to the followings were aggregated: access to humanitarian assistance, access to reconstruction materials, access to cash grants, and access to local government assistance.

Level of education: an explanatory variable measured by respondents' selection of one option from a list ranging from "no education" to post-graduate qualification. Education has been identified as a significant factor in post disaster recovery (Barakat et al., 2013).

Access to land: an explanatory variable measured using a five-point likert scale question asking about the level of respondents' access to land. This is included in the light of the extensive literature on the link between property rights and access to formal credit and other forms of resources (De-Soto, 2000).

Income generating activities: an explanatory variable, measured using a likert scale question about the level of income generating activities.

Quality of reconstructed houses: again, this explanatory variable is measured using a multi-dimensional construct in which respondents were asked to use 5-point likert scale items rate the quality of reconstructed houses based on the followings: durability, resilience, quality, cost, and safety. Quality of reconstructed houses has not received sufficient attention in the literature; yet, it is key to evaluating the long-term impact and effectiveness of humanitarian interventions in disaster situations.

\subsection{Analysis}

Descriptive statistics were used to obtain the frequency distributions; cross-tabulation analyses and Chisquare tests were run to identify the relationship between variables. One sample t-test was used with confidence level of $95 \%$ to compare the sample mean with population mean and to test whether the t-value is high and statistically significant, and to determine whether the null hypothesis is rejected. Multiple regression analyses, followed by hierarchical regressions were conducted to assess the combined effects of the independent variables of access to resources and other socio-economic variables of age, gender, level of education, construction specialists, building materials and level of income generating activities (Bryman, 2016). The model was specified as follows: 
$\mathrm{Y}=\mathrm{B}_{0}+\mathrm{B}_{1} \mathrm{X}_{1}+\mathrm{B}_{2} \mathrm{X}_{2}+\mathrm{B}_{3} \mathrm{X}_{3}+\mathrm{B}_{4} \mathrm{X}_{4}+\mathrm{B}_{5} \mathrm{X}_{5}+\mathrm{B}_{6} \mathrm{X}_{6}+\mathrm{B}_{7} \mathrm{X}_{7}+\mathrm{B}_{8} \mathrm{X}_{8}+\mathrm{B}_{9} \mathrm{X}_{9}+\mathrm{B}_{10} \mathrm{X}_{10}+\mathrm{B}_{11} \mathrm{X}_{11}+\varepsilon$

Where,

$\mathrm{Y}$ is the dependent variable

$\beta_{0}$ is the $\mathrm{p}$-dimensional parameter or intercept

$\mathrm{X}_{1}$ is the age of the respondent

$\mathrm{X}_{2}$ is the gender of the respondent

$\mathrm{X}_{3}$ is the monthly income in BD Taka

$\mathrm{X}_{4}$ is the marital status of the respondent

$\mathrm{X}_{5}$ is the level of education

$\mathrm{X}_{6}$ is the level of access to land

$\mathrm{X}_{7}$ is the access to sufficient resources

$\mathrm{X}_{8}$ is the level of access to income generating activities

$\mathrm{X}_{9}$ is the level of access to the quality of building materials

$\mathrm{X}_{10}$ is the level of access to construction expertise

$\mathrm{X}_{11}$ is the level of access to technological application

$\mathrm{B}_{1}, \mathrm{~B}_{2}, \mathrm{~B}_{3}, \mathrm{~B}_{4}, \mathrm{~B}_{5}, \mathrm{~B}_{6}, \mathrm{~B}_{7}, \mathrm{~B}_{8}, \mathrm{~B}_{9}, \mathrm{~B}_{10}$, and $\mathrm{B}_{11}$ are the regression coefficients for independent variables, $\varepsilon$ is the random variable called the error term.

ANOVA (Analysis of Variance) was also conducted in order to assess the overall significance of the model used by using $\mathrm{p}<0.05$ as a criteria of level of significance. The adjusted R-Square values provide indications of the contribution of the model to the overall variance in the model. Qualitative data is analysed using NVivo version 10. The data was thematically analysed to explore the trends and different opinions of key stakeholders about the impact of access to resources and level of income generating activities towards the post-disaster housing reconstruction.

\section{RESULTS AND DISCUSSIONS}

\subsection{Descriptive statistics and Chi-square tests}

In this sub-section, an overview of frequency distributions for housing recovery and rate of housing recovery are provided in table 2. This is followed by further frequency data and descriptive statistics on access to resources and selected socio-economic factors in table $3 \mathrm{a}$ and $3 \mathrm{~b}$. Finally, a descriptive statistics of the likert scale items used to measure the constructs are summarised in table $3 \mathrm{c}$. 


\section{Access to resource and rate of housing reconstruction}

Housing recovery rate is defined as the percentage of affected villagers who have recovered and reconstructed their houses after cyclone Sidr and Aila in Satkhira and Bagerhat in Bangladesh. The data on frequency distribution table shows that more than $69 \%$ affected respondents have recovered their houses and more than $30 \%$ respondents did not recover their houses even 7 years after cyclone.

\section{INSERT TABLE 2 HERE}

The results of frequency distribution table show that $94 \%$ population from the total respondents have answered 'no' to the question of is your current house cyclone resilient? And only $6 \%$ respondents think their houses are strong enough to protect them in upcoming cyclone. It should be noted that this question is only gauging residents' perception about the state and quality of their houses, and cannot be deemed an objective measure of whether or not the houses are resilient. To buttress this point, the frequency data shows that more than $81 \%$ of the respondents are very dissatisfied with their houses whether they are cyclone resilient or not, and only 2 respondents are satisfied with the resilient houses, and more that $95 \%$ respondents think that they are not safe in their current houses. For deeper understanding of the states of the houses and other related variables, more specific indicators were incorporated into the likert scale items summarised in table $3 \mathrm{c}$.

\section{Housing reconstruction and access to resources}

The results of the cross tabulation, t-test and Chi-square test are summarised in the tables that follow. The Chi-square values are high for all determinants with the significance levels of .000 except .045 for beneficiary's satisfaction. This indicates an association between access to resources and housing reconstruction. These results are summarised in tables $3 \mathrm{a}$ and $3 \mathrm{~b}$ below.

\section{INSERT TABLES 3A AND 3B HERE}

The chi-square value of level of access to resources is $12.182^{a}$ and level of significance (2-sided) is .016 indicating a strong significance.

\section{Access to resources and vulnerability reduction}

The T-tests and Chi-square results show that the average mean value of resilience to withstand disasters is 1.53 which represents their inability to prepare, cope, and respond to disasters. The Chi-square value of all the determinants are quite high and level of significance is .000 , indicating a strong association between access to resources can resilience and capacity to withstand future disasters. This result also shows that more than $75 \%$ of the respondents have very low level of resilience in withstanding disasters. This result is quite consistent with findings of Bosher et al. (2007) which showed in a study of resource accessibility and vulnerability that most of the people are vulnerable due to low levels of education, poor housing and lack of 
involvement with other organisations have a lesser capability to withstand the onslaught of disasters due to poverty.

\section{INSERT TABLE 3C HERE}

\section{Access to resources and poverty reduction}

The results show the average mean value of poverty reduction determinants is below 1.5 which represents their poverty to prepare, cope, respond to disasters and rebuild their houses. The percentages are very low in terms of affordability (61.8\%), capability to meet regular needs $(57.6 \%)$, access to recreation $(69.1 \%)$, per capita income $(62.5 \%)$, bearing regular expenses $(58 \%)$ and satisfaction with income (66\%). The Chi-square value of all the determinants is quite high and level of significance is .000 indicates that access to resources can influence disaster victims' ability to build up their capacity to meet regular needs and bear regular expenses that in turn will increase their resilience.

\section{Access to resources and quality of reconstructed houses}

A five-point Likert scale was introduced to measure the level of quality of reconstructed houses depending on the determinants of durability, cultural acceptance, maintaining building codes, community participation in the decision process, high modern design, the use of technology, hazard resistant structures and retrofitting, resilience to hazard for the respondent's safety and security in the houses. According to their responses mentioned in table no.8, the mean values of durability, cultural acceptance, maintaining building code, community participation and technological use are 1.59. 1.43, 1.34, 1.40, 1.27 respectively which means that reconstructed houses are not durable, not culturally accepted, are not maintained by building codes, exhibit lack of community participation and use insufficient technology.

\section{INSERT TABLE 4 HERE}

The average mean value of other factors that determine the safety and security of the respondents during strong storms is below 1.20, which indicates that disaster victims are not safe during cyclones. As can be seen from Table 9, the responses translate to $41.7 \%$ of the respondents in terms of durability, $45.5 \%$ in cultural acceptance, $49.7 \%$ in terms of building code, $47.9 \%$ in community participation, $54.2 \%$ in technological use, $57.6 \%$ in hazard resistance and $61.5 \%$ in resilience to hazards. The respondents thus confirmed the very low quality of the reconstructed houses and the safety and security vulnerabilities during strong cyclones. The Chi-square values of all the determinants are quite high and level of significance is .000 for all determinants. Furthermore, the regression result shows that the Beta Coefficient of .414 at significance level of 0.000 and adjusted R-squared value of .215 indicate that access to resources has a strong positive impact on the determinants of quality of reconstructed houses. This leads to rejection of the null hypothesis 
number nine affirming the suggestion that people having access to resources can rebuild durable and cyclone resistant houses.

\section{Access to resources and beneficiaries' satisfaction}

The results of the descriptive statistics show that the average mean value of the factors that determine the satisfaction of beneficiary on reconstructed houses is less than 1.25 , which indicates that disaster victims are not happy at all on their current houses. As can be seen from Table 8, more than $80 \%$ of the respondents in terms of cyclone resilient, $70.4 \%$ in terms of safety, $72.9 \%$ in terms of cost-efficiency, $76.0 \%$ in technological use, $82.0 \%$ in giving importance to local culture, $77.8 \%$ in sustainability, $78.8 \%$ in community participation, and $82.3 \%$ in coping and adapting capacity have confirmed that they are highly dissatisfied on the quality of the reconstructed houses. The Chi-square test and t-value of all the determinants are quite high and level of significance is .000 for all determinants. This is quite similar with the findings of several scholars (see Ahmed and Charlesworth, 2015; Gunasekera et al., 2015; Jha et al., 2010; Lloyd-Jones, 2006; Lyons, 2009; The World Bank, 2013b), in the sense that the majority of the respondents have expressed poor satisfaction with the quality of the houses constructed by either international agencies or local government.

\subsection{Regression analysis}

The regression result (table 5) shows that, in support of hypothesis 1, access to resources, level of access to construction expertise and access to technological innovations are significant predictors of post-disaster housing reconstruction. This is the case after controlling for socio-economic variables such as age, gender, marital status, level of education and monthly income. Specifically, the findings indicate that for every unit increase in access to resources, housing reconstruction improves by 0.14 . Similarly, access to resources significantly influences vulnerability reduction by 0.25 units. Access to technological innovation and construction expertise are also significant for vulnerability reduction at $10 \%$ level of significance, with coefficients of 0.065 and 0.11 respectively. Access to technological innovation also helps resident to mitigate some of the adverse effects of cyclones. For example, access to digital technology is known to have a major impact on information dissemination before, during and after disasters. In the same vein, access to construction expertise improves the likelihood of household constructing more resilient houses that would in turn reduce their vulnerability to cyclones. Access to resources is also the main predictor of quality of reconstructed houses, beneficiaries' satisfaction and livelihood recovery, with coefficients of $0.313,0.411$, an 0.153 , respectively. These support hypothesis 3 that disaster victims with better access to resources are more able to recover from shocks and stresses arising from the disaster. Furthermore, additional data on access to resources show that people who have access to resources have rebuilt their houses by themselves, but the percentage is very low, as only $4.6 \%$ respondents have a sufficient amount of resources to rebuild their houses without external intervention. This result is consistent with findings of Bosher et al. (2007 and 
O'Brien et al. (2006) that disaster victims have very limited access to resources and access to resources significantly influences the disaster victims to rebuild their houses.

\section{INSERT TABLE 5 HERE}

In summary, the results of this regression analysis show that access to resources exerts a significant impact in post-Sidr and Aila housing reconstruction. However, the frequency distribution (table 6)also show that more than $86 \%$ of respondents are living in poverty, which in effect indicates their low level of access to resources.

\section{INSERT TABLE 6 HERE}

For robustness of the analysis, this study also employed a three-stage hierarchical regression analysis, incorporating additional variables to the original regression model. The hierarchical regression analysis provides information about changes in predictability associated with predictor variables entered in different steps of the regression. The changes in $\mathrm{R}^{2}$ and the levels of significance in the regression equations were used to determine the existence and strength of relations in the models created. The results of hierarchical regression analysis are given below in table 7.

\section{INSERT TABLE 7 HERE}

\section{Model 1}

$F(5,272)=4.2, \mathrm{p}<.001, \mathrm{R}^{2}=-.007$

Level of education $\beta=.051, t(5,272)=4.2, \mathrm{p}<.001, \mathrm{pr}^{2}=0.002$

\section{Model 2}

$F(5,267)=4.1, \mathrm{p}<.001, \mathrm{R}^{2}=0.006$

Access to resources $\beta=.174, t(5,267)=4.1, \mathrm{p}<.001, \mathrm{pr}^{2}=0.023$

\section{Model 3}

$F(5,262)=2.5, \mathrm{p}<.029, \mathrm{R}^{2}=0.011$

Income generating activities $B=-0.102, t(5,262)=2.5, \mathrm{p}<.029, \mathrm{pr}^{2}=0.011$

Where $\mathrm{F}=$ Degrees of freedom $(\mathrm{DF} 1, \mathrm{DF} 2)=\mathrm{F}$ change value, $\mathrm{P}=$ probability value and $\mathrm{B}$ represents standardized Beta Coefficient. 
Table 7 presents the regression coefficients of dependent, independent and predictor variables. In the first step, age of the respondents, gender, marital status, monthly income and level of education were entered as independent variables and housing reconstruction was entered as dependent variable. The result in the first step shows that there is a significant change between adjusted $\mathrm{R}^{2}$ and $\mathrm{R}^{2}$ change and gender of the respondents emerged as significant predictor variable with the value of .000 . The adjusted $\mathrm{R}^{2}$ explains that $5.5 \%$ variance on the predictor variable of gender of the respondents and $\mathrm{R}^{2}$ change is $7.20 \%$. This result shows that gender of the respondents plays a crucial role in post-disaster housing reconstruction of disaster victims, confirming the results of the linear regression in table 5.

In the second step, access to resources, access to land, access to institutional resources, access to community resources, and access to building materials were entered as independent variable and access to resources and access to institutional resources were emerged as statistically significant with the $\mathrm{p}$ value of .012 and .001 respectively. The second model indicates a $6.6 \%$ in the adjusted $\mathrm{R}^{2}$. The result affirms the hypothesis number one of this study that disaster victims with access to resources are more likely to rebuild houses by themselves than people having no access to resources.

Similarly, in the third step, socio-economic and demographic variables of income generating activities, access to technological application, access to financial resources, access to construction specialists, and access to human resources were entered to determine the interaction and effect of each variables on depending variable and to compare each model. However, the results show that income generating activities, access to community resources, and access to construction specialists were statistically significant with the value of .016, .036 and .021 respectively. It also indicates a $4 \%$ improvement in the adjusted $\mathrm{R}^{2}$ from model 2 to model 3. This result affirms the hypothesis number eight that people with access to Income Generating Activities (IGA) aeee more likely to reconstruct their houses than people with limited access to IGA.

In summary, the first model shows that degree of freedom is 5 and 272 and $\mathrm{f}$ change value is .001 which is statistically significant. The second model is statistically significant with the p value of .001. The third model is statistically significant as well with the $\mathrm{p}$ value of .029 . Overall, the hierarchical regression analysis confirms the earlier regression analysis, indicating that access to resources and income generating activities can play significant role in terms reconstructing disaster victims' houses. 


\section{KEY THEMES FROM EXPLORATORY INTERVIEWS}

The analysis of qualitative data from semi-structured and in-depth interview revealed some significant issues that actually can determine the disaster victim's level of access to resources, factors that generally affect housing reconstruction and remit to rebuild dynamic cyclone resilient houses for cyclone Sidr and Aila affected people. Thematic analysis of the in-depth interviews threw up the following main issues.

\subsection{Respondent's level of access to resources for PDHR}

Access to required resources is pre-requisite for disaster victims to rebuild their houses. They cannot rebuild houses without sufficient amount of resources. They need resources as well construction materials to reconstruct houses. The results of quantitative analysis shows that people affected by Cyclone Sidr and Aila are very poor. They cannot rebuild houses due to insufficient amount of resources.

However, the qualitative data analysis from semi-structured interview also shows that people affected by both cyclones Sidr and Aila has very low level of access to resources. The data analysis shows that at least 14 respondents mentioned that disaster victims have very low level of access to resources to rebuild their houses

\subsection{Materials used for rebuilding houses}

Disaster victims suffer from lack of resources; they cannot rebuild houses by themselves. In most of the cases, local government, national and international NGOs, such as UNDP, OXFAM and IFRC rebuild their houses. In a few cases, houses are built by disaster victims or their relatives. However, the percentage of self-reconstruction is very low, at $17.8 \%$ of all reconstructed houses. In terms of housing reconstruction, in most cases materials such as bamboo, CGI sheet, wood, mud and RCC pillars are used to rebuild their houses.

\subsection{Housing quality, political influence and disaster vulnerability}

The conditions of existing houses are fragile (see figure 2). It has been seen that some of the houses built by various organisation including Islamic Relief have already been blown away in the study area of Gabura union Satkhira. The quantitative data analysis confirmed that more than 50\% houses are built by permanent tin room and only $3.80 \%$ houses are built with reinforced concrete. This implies that most of the houses are built with corrugated tin which can be blown away in strong wind. In other words, these types of houses cannot give them safety during category 4 cyclone like Sidr. For example, one of the local government officials stated: 
I think most of the houses in coastal area of southern part of Bangladesh after cyclone Sidr and Aila are not cyclone resilient or tidal surge resilient, they are very fragile and deplorable because those houses are built with bamboo, muds and CGI sheets, it cannot protect them in tidal surge as well (Respondent 1, BRAC Official, April 2016 ).

...90\% organisations use corrugated tin and GI sheets as a routine materials and side walls but corrugated tin and CGI sheets are not cyclone resilient. Therefore, we cannot say that those houses are cyclone resilient. (Respondent 2, Habitat for the Humanity Official, April 2016).

Furthermore, his study reveals that the houses which have been built by local governments and UNDP are built with concrete and cyclone-resistant materials. However, as the following comments reveal, such houses are very few, and usually available to few people who have political connections, or those who are willing to offer bribes:

I did not receive any assistance from government or organisations. The local government officials told me to give him bribe to put my name on the list. As I have no money to give him, they did not put my name on the lists...(Affected villagers No 101, April 2016)

This supports hypothesis 2 that people with less access to political power are more vulnerable, because they are less able to access adequate humanitarian assistance necessary for construction of cycloneresilient houses. This distance from political power is aggravated by poverty, but can perhaps be mitigated by some forms of collective action on the part of the vulnerable poor. Furthermore, this underlines the need for better, may be direct, administration of humanitarian intervention by multilateral agencies.

\subsection{Remit to rebuild dynamic cyclone resilient houses}

The People in cyclone Sidr and Aila affected areas are very vulnerable. Lack of available resources, lack of education, and lack of training and skills exacerbate their vulnerability. The vulnerability of their settlements to a cyclone is linked to three mutually reinforcing factors: its siting, the probability that a cyclone will occur, and the degree to which its structures can be damaged by it. Houses are considered vulnerable if they are built with poor and cheap construction materials such as mud, CGI sheets and corrugated tins, and with little or no engineering skills and design. Such houses are most vulnerable to cyclones because they are lightweight, typically structures built with wood frames. In older buildings the wood has deteriorated and weakened the walls.

Construction of cyclone resilient houses is very difficult due to the acute poverty and lack of resources for disaster victims. They cannot buy materials such as sand, iron rod, brick, and cement which are expensive. Besides these, locally available engineers are very limited thereby limiting their opportunities to build cyclone resilient houses. Most of the respondents interviewed mentioned that it is very difficult to build cyclone resilient houses. Some respondents also mentioned that disaster victims first need to recover their 
livelihoods in order to reduce poverty. However, this study explores ways to rebuild cyclone resilient houses after analysing all the data from semi-structured interview and the opinions and suggestions from the expert interviewees.

The qualitative data analysis also support the quantitative findings that dynamic cyclone resilient houses can be built on the basis of some factors which are: access to resources, applying engineering skills and training in reconstruction, cyclone resilient materials for reconstruction, access to land, considering cultural aspects, technological use in reconstruction, concrete roofing, access to education, microfinance, and government and stakeholder involvement in reconstruction. Access to resources is the most cited factor. Nine respondents out of twenty mentioned that access to resources is the main issue that disaster victims must have to in order to rebuild cyclone resilient houses. Likewise, consideration of tidal surge in reconstruction is significant, and several respondents highlighted the need to have a room in the first floor of the house so that at the time of tidal surge, they can take shelter in the room upstairs.

The model below (figure 3) describes how durable and resilient houses can be obtained through different critical stages. It draws information from quantitative analysis, thematic analysis of the in-depth interviews and the synthesis of various post-disaster housing reconstruction theories.

\section{INSERT FIGURE 3 HERE}

As the figure shows, there are eight critical elements that play a pivotal role in reconstructing durable and resilient houses. For example, active community participation is a prerequisite to resilient houses. This is because community participation in PDHR can empower the beneficiaries in important decisionmaking processes. This approach ensures that their voices are heard and the community is able to take ownership of the project. Similarly, involvement of governments can increase the accountability of the PDHR projects and cultural appropriateness can increase the acceptance of the delivered projects to the beneficiaries.

\section{CONCLUSION}

Access to resource is one of the most significant determinants that work as a catalyst in post-disaster housing reconstruction projects. This study underlines the fact that cyclone disasters have tremendous impact on housing provision for vulnerable people. These consequences cannot be totally prevented but it is possible to minimize them and to reduce peoples' vulnerability and increase their satisfaction on reconstructed houses. Access to resource exerts a significant influence on beneficiary's satisfaction on reconstructed houses, reducing their vulnerability, poverty level and thereby improving their livelihoods recovery. The impact of access to resources was found most significant among other socioeconomic variables. Level of 
income generating activities, access to education and access to available land appear to be very significant as income generating activities can enhance their livelihood recovery. Furthermore, access to education can increase awareness, training and skills, and access to land can help disaster victims to rebuild their houses. The overall implication of the findings affirms the main hypothesis that people with access to resources are more likely to reconstruct their houses by themselves than people with limited access to resources.

\section{REFERENCES}

Ahmed, I. (2011) An overview of post - disaster permanent housing reconstruction in developing countries, International Journal of Disaster Resilience in the Built Environment, 2 (2), pp. 148-164.

DOI:10.1108/17595901111149141.

Ahmed, I. and Charlesworth, E. (2015) Housing and Resilience: Case Studies from Sri Lanka, in: Shaw, R. (ed.) Recovery from the Indian Ocean Tsunami: A Ten-Year Journey. Tokyo: Springer Japan, pp. 417-434. Akter, S. and Mallick, B. (2013) The poverty-vulnerability-resilience nexus: Evidence from Bangladesh, Ecological Economics, 96, pp. 114-124. DOI:10.1016/j.ecolecon.2013.10.008.

Bakeri, A. and Bakar, A. (2011) A Survey of Information Resources Required by Ulama to Perform Their Work Roles : A Case Study of Borno State, Libray Philosophy and Practice 2011.

Bank, T. W. (2014) Bangladesh - Planning and implementation of post-Sidr housing recovery : practice, lessons and future implications - recovery framework case study. Available from:

http://documents.worldbank.org/curated/en/979121493705545377/Bangladesh-Planning-andimplementation-of-post-Sidr-housing-recovery-practice-lessons-and-future-implications-recoveryframework-case-study [Accessed 26 January 2018].

Barakat, S., Connolly, D., Hardman, F. and Sundaram, V. (2013) The role of basic education in postconflict recovery, Comparative Education, 49 (2), pp. 124-142. DOI:10.1080/03050068.2012.686259. Barenstein, J. D. and Isaac, D. P. (2007) Post-disaster housing reconstruction Current trends and sustainable alternatives for tsunami-affected communities in coastal Tamil Nadu. Available from: http://www.chs.ubc.ca/archives/files/Post-Disaster housing recounstruction current trends and sustianable alternatives.pdf

Bosher, L., Penning-Rowsell, E. and Tapsell, S. (2007) Resource Accessibility and Vulnerability in Andhra Pradesh: Caste and Non-Caste Influences, Development and Change, 38 (4), pp. 615-640. DOI:10.1111/j.1467-7660.2007.00426.x.

Burnell, J. (2010) Literature review: what works well in shelter after disaster? Oxford. Available from: http://architecture.brookes.ac.uk/research/cendep/media/Jeni Burnell_Literature review_sharing of initial findings and thoughts.pdf

Centre for Research on the Epidemiology of Disasters (2017) EM-DAT | The international disasters database, EM-DAT Report. Available from: http://www.emdat.be/ [Accessed 26 January 2018]. Chang, Y., Wilkinson, S., Potangaroa, R. and Seville, E. (2010) Resourcing challenges for post-disaster housing reconstruction: A comparative analysis, Building Research and Information, 38 (3), pp. 247-264. DOI:10.1080/09613211003693945.

Chang, Y., Wilkinson, S., Potangaroa, R. and Seville, E. (2012) Resourcing for post - disaster reconstruction: a comparative study of Indonesia and China, Disaster Prevention and Management: An International Journal, 21 (1), pp. 7-21. DOI:10.1108/09653561211202674.

Da Silva, J. and Batchelo, V. (2010) Indonesia: Understanding agency policy in a national context, in: Michal Lyons, Theo Schilderman, and Camilo Boano (eds.) Building Back Better. Rugby: Practica Action Publishing, pp. 113-134.

De-Soto, H. (2000) The mystery of capital: why capitalism triumphs in the west and fails everywhere else. London, UK: Bantam Press.

de Bangladesh, G. (2008) Cyclone Sidr in Bangladesh: Damage, Loss and Needs Assessment for Disaster 
Recovery and Reconstruction.

Duyne Barenstein, J. E. and Leemann, E. (2012) Post-disaster reconstruction and change : communities' perspectives. CRC Press.

Freeman, P. K. (2004) Allocation of post-disaster reconstruction financing to housing, Building Research \& Information, 32 (5), pp. 427-437. DOI:10.1080/0961321042000221016.

Gunasekera, R., Ishizawa, O., Aubrecht, C., Blankespoor, B., Murray, S., Pomonis, A. and Daniell, J. (2015) Developing an adaptive global exposure model to support the generation of country disaster risk profiles, Earth-Science Reviews, 150, pp. 594-608. DOI:10.1016/J.EARSCIREV.2015.08.012.

Haider, M. Z. and Ahmed, M. F. (2014) Multipurpose uses of cyclone shelters: Quest for shelter sustainability and community development, International Journal of Disaster Risk Reduction, 9, pp. 1-11. DOI:10.1016/J.IJDRR.2014.03.007.

Hakim, S. S. (2009) Sustainability of assisted shelter projects in post-cyclone communities: The Southkhali case, Bangladesh, BRAC University Journal, 6 (1), pp. 85-95. Available from:

http://dspace.bracu.ac.bd/xmlui/handle/10361/456 [Accessed 6 February 2018].

Hidayat, B. (2013) The role of knowledge communication in the effective management of post-disaster reconstruction projects in Indonesia. University of Salford. Available from :

http://usir.salford.ac.uk/30809/1/thesis-report-Benny-Hidayat-final.pdf

IFRC (2010) Bangladesh: Cyclone Sidr Final Report Emergency appeal $n^{\circ}$ MDRBD003. Available from: http://www.ifrc.org/docs/appeals/07/mdrbd003fr.pdf

Ika, L. A., Diallo, A. and Thuillier, D. (2012) Critical success factors for World Bank projects: An empirical investigation, International Journal of Project Management, 30 (1), pp. 105-116.

DOI:10.1016/j.ijproman.2011.03.005.

Jha, A. K., Barenstein, J. D., Phelps, P. M., Pittet, D. and Sena, S. (2010) Safer homes, stronger communities : a handbook for reconstruction after natural disaster : Safer homes, stronger communities : a handbook for reconstructing after natural disasters (English)|The World Bank. Washington, D.C.: World Bank. Available from: http://documents.worldbank.org/curated/en/290301468159328458/Safer-homesstronger-communities-a-handbook-for-reconstructing-after-natural-disasters

Kabir, R. (2009) Post-Cyclone Sidr Family Shelter Construction in Bangladesh - Documentation of Plans and Processes, Shelter Working Group.

Karim, A. and Noy, I. (2015) The ( mis ) allocation of public spending in a low income country: Evidence from disaster risk reduction spending in Bangladesh (No. 5). Wellington, New Zealand.

Kulatunga, U., Wedawatta, G., Amaratunga, D. and Haigh, R. (2014) Evaluation of vulnerability factors for cyclones: The case of Patuakhali, Bangladesh, International Journal of Disaster Risk Reduction, 9, pp. 204-211. DOI:10.1016/J.IJDRR.2014.05.011.

Lin Moe, T., Gehbauer, F., Senitz, S. and Mueller, M. (2007) Balanced scorecard for natural disaster management projects, Disaster Prevention and Management: An International Journal, 16 (5), pp. 785806. DOI:10.1108/09653560710837073.

Lloyd-Jones, T. (2006) Mind the Gap! Post-disaster reconstruction and the transition from humanitarian relief. London. Available from: www.rics.org

Lyons, M. (2009) Building Back Better: The Large-Scale Impact of Small-Scale Approaches to Reconstruction, World Development, 37 (2), pp. 385-398. DOI:10.1016/j.worlddev.2008.01.006. Mallick, B., Ahmed, B. and Vogt, J. (2017) Living with the Risks of Cyclone Disasters in the SouthWestern Coastal Region of Bangladesh, Environments, 4 (1), pp. 13. DOI:10.3390/environments4010013. Minar, M. H., Hossain, M. B. and Shamsuddin, M. D. (2013) Climate Change and Coastal Zone of Bangladesh: Vulnerability, Resilience and Adaptability, Middle-East Journal of Scientific Research, 13 (1), pp. 114-120. DOI:10.5829/idosi.mejsr.2013.13.1.64121.

Nadiruzzaman, M. and Paul, B. K. (2013) Post-Sidr public housing assistance in Bangladesh: A case study, Environmental Hazards, 12 (2), pp. 166-179. DOI:10.1080/17477891.2012.759523.

Nazara, S. and Resosudarmo, B. P. (2007) Aceh-Nias Reconstruction and Rehabilitation: Progress and Challenges at the End of 2006. Tokyo. Available from: http://www.adbi.org/discussion- 
paper/2007/06/26/2288.acehnias.reconstruction.rehabilitation/

O’Brien, G., O'Keefe, P., Rose, J. and Wisner, B. (2006) Climate change and disaster management, Disasters, 30 (1), pp. 64-80. DOI:10.1111/j.1467-9523.2006.00307.x.

Paul, S. K. and Routray, J. K. (2013) An analysis of the causes of non-response to cyclone warnings and the use of indigenous knowledge for cyclone forecasting in Bangladesh, in: Climate Change and Disaster Risk Management. Berlin: Springer, pp. 15-39.

Silva, J. da and Batchelor, V. (2010) Indonesia: Understanding agency policy in a national context, in: Lyons;, M. and Schilderman, T. (eds.) Building Back Better. Rugby, Warwickshire, United Kingdom: Practical Action Publishing, pp. 135-161.

Singh, B. and Wilkinson, S. (2008) Post-disaster Resource Availability following a Wellington Earthquake: Aggregates, Concrete and Cement. Available from: https://www.researchgate.net/profile/Suzanne_Wilkinson/publication/267703830_Postdisaster_Resource_Availability_following_a_Wellington_Earthquake_Aggregates_Concrete_and_Cement/ links/5463ce400cf2cb7e9da99a9c.pdf

The World Bank (2013a) Building Urban Resilience. DOI:10.1596/978-0-8213-8865-5.

The World Bank (2013b) Strong, Safe, and Resilient: a stratgeic policy guide for Disaster Risk Management in East Asia and the Pacific, Jha, A. K. and Stanton-Geddes, Z. (eds.) . The World Bank. Tobin, G. A. (1999) Sustainability and community resilience : the holy grail of hazards planning?, Environmental Hazards, 1 (1), pp. 13-25. DOI:10.3763/ehaz.1999.0103.

United Nations Development Programme (2015) National Human Development Report , 2015- Human Security and Human Development in Nigeria. Available from:

http://www.ng.undp.org/content/nigeria/en/home/library/poverty/national-human-development-report$\underline{2016 . h t m l}$ 
Table1: Summary of hypotheses

\section{LIST OF TABLES}

\begin{tabular}{|l|l|}
\hline S/N & Hypotheses \\
\hline 1 & $\begin{array}{l}\text { Disaster victims with access to resources are more likely to rebuild houses by themselves than people having no } \\
\text { access to resources }\end{array}$ \\
\hline 2 & People with limited access to power and political influence are more susceptible to living in unsafe conditions \\
\hline 3 & Disaster victims with assets have better opportunities to recover from shocks, stresses and destruction of houses. \\
\hline 4 & People with access to resources cope better with impediments to housing reconstruction. \\
\hline 5 & Disaster victims with access to resources can rebuild durable and cyclone resistant houses. \\
\hline
\end{tabular}

Table 2. Housing recovery, types of house and waiting time in years

\begin{tabular}{lclc}
\multicolumn{2}{l}{ Access to resources and rate of housing reconstruction } \\
\hline kutcha house & $25.60 \%$ & Years to receive houses & $21.40 \%$ \\
pucca house & $11.90 \%$ & After one year & $21.10 \%$ \\
detached house & $4.60 \%$ & After three years & $28.40 \%$ \\
tin-shed house & $23.50 \%$ & After five years & $1.10 \%$ \\
temporary fragile house & $6.70 \%$ & After seven years & $79.30 \%$ \\
Rate of housing recovery & & Reasons of non-cyclone resilient houses & $1.10 \%$ \\
Yes & $69.50 \%$ & Poorly made & $6.30 \%$ \\
No & $30.50 \%$ & Lack of maintaining building code & $9.50 \%$ \\
Cyclone resilient houses & & Corruption & $1.80 \%$ \\
Yes & $94 \%$ & Beneficiary's opinion is not considered & \\
No & $6 \%$ & Ignoring local culture & \\
\hline
\end{tabular}

Table 3a frequency distribution of access to resources

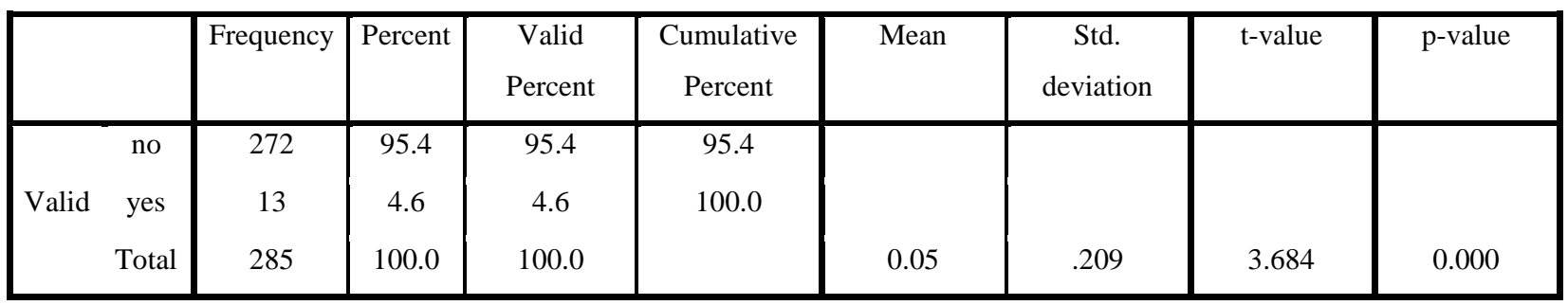

Table 3b: Housing reconstruction and socio-economic factors

\begin{tabular}{cccc} 
Pearson Chi-square & Value & DF & Asymp.sig (2 sided) \\
\hline Reconstruction & 12.182 & 4 & .016 \\
Vulnerability reduction & 84.346 & 6 & .000 \\
Poverty reduction & 66.802 & 4 & .000 \\
Livelihood recovery & 53.609 & 2 & .000 \\
Quality of reconstructed houses & 150.785 & 3 & .000 \\
Beneficiary's satisfaction & 4.001 & 1 & .045 \\
\hline
\end{tabular}

Table 3c: Factors determining respondent's socio-economic condition 


\begin{tabular}{|c|c|c|c|c|c|c|c|c|c|c|}
\hline $\begin{array}{l}\text { Access to resources and vulnerability } \\
\text { reduction(Constant) }\end{array}$ & Mean & $\begin{array}{l}\text { T- } \\
\text { value }\end{array}$ & SD & $\begin{array}{l}\text { Chi- } \\
\text { square }\end{array}$ & $\begin{array}{l}\text { P- } \\
\text { value }\end{array}$ & $\begin{array}{l}\text { very } \\
\text { low }\end{array}$ & low & moderate & high & $\begin{array}{l}\text { very } \\
\text { high }\end{array}$ \\
\hline Resilience to cyclone & 1.53 & 8.462 & 3.045 & 65.737 & .000 & $78.50 \%$ & $16.70 \%$ & $3.80 \%$ & - & - \\
\hline Building capacity to resilience & 1.33 & 37.683 & 0.597 & 54.955 & .000 & $71.50 \%$ & $22.60 \%$ & $4.50 \%$ & - & $0.30 \%$ \\
\hline $\begin{array}{l}\text { Reducing underlying risk factors } \\
\text { Strengthen disaster preparedness for effective }\end{array}$ & 1.26 & 38.926 & 0.546 & 66.073 & .000 & $77.80 \%$ & $17.40 \%$ & $3.10 \%$ & $0.70 \%$ & - \\
\hline response & 1.26 & 38.376 & 0.552 & 70.454 & .000 & $77.80 \%$ & $16.30 \%$ & $3.50 \%$ & $0.70 \%$ & - \\
\hline \multicolumn{11}{|l|}{$\begin{array}{l}\text { Access to resources and poverty reduction } \\
\text { (Constant) }\end{array}$} \\
\hline Affordability & 1.45 & 29.878 & 0.82 & 59.356 & .000 & $61.80 \%$ & $31.90 \%$ & $4.20 \%$ & $0.40 \%$ & - \\
\hline Capability to meet regular needs & 1.53 & 25.934 & 0.998 & 76.067 & .000 & $57.60 \%$ & $35.80 \%$ & $4.50 \%$ & $0.30 \%$ & $0.70 \%$ \\
\hline Access to recreation & 1.37 & 28.76 & 0.804 & 123.286 & .000 & $69.10 \%$ & $24.30 \%$ & $4.50 \%$ & $0.30 \%$ & $0.70 \%$ \\
\hline Per capita income & 1.39 & 42.947 & 0.543 & 63.61 & .000 & $62.50 \%$ & $32.30 \%$ & $3.10 \%$ & $0.70 \%$ & $0.30 \%$ \\
\hline Bearing regular expenses & 1.45 & 42.133 & 0.577 & 59 & .000 & $58.00 \%$ & $35.40 \%$ & $4.50 \%$ & $0.70 \%$ & $0.40 \%$ \\
\hline Satisfaction over income & 1.50 & 20.339 & 1.246 & 76.084 & .000 & $66.00 \%$ & $27.10 \%$ & $4.90 \%$ & $0.70 \%$ & $0.30 \%$ \\
\hline \multicolumn{11}{|l|}{$\begin{array}{l}\text { Access to resource and quality of } \\
\text { reconstructed houses (Constant) }\end{array}$} \\
\hline Durable & 1.59 & 27.373 & 0.829 & 94.39 & .000 & $41.70 \%$ & $19.40 \%$ & $7.30 \%$ & $2.10 \%$ & $0.30 \%$ \\
\hline Cultural acceptance & 1.43 & 32.401 & 0.628 & 38.875 & .000 & $45.50 \%$ & $19.80 \%$ & $5.20 \%$ & - & - \\
\hline maintaining building codes & 1.34 & 34.681 & 0.551 & 34.729 & .000 & $49.70 \%$ & $18.40 \%$ & $2.40 \%$ & - & - \\
\hline Community participation & 1.40 & 31.308 & 0.64 & 34.556 & .000 & $47.90 \%$ & $17.70 \%$ & $4.90 \%$ & - & $0.30 \%$ \\
\hline Technological use & 1.27 & 34.466 & 0.528 & 28.571 & .000 & $54.20 \%$ & $13.90 \%$ & $2.80 \%$ & - & - \\
\hline \multicolumn{11}{|l|}{$\begin{array}{l}\text { Access to resources and livelihood recovery } \\
\text { (Constant) }\end{array}$} \\
\hline $\begin{array}{l}\text { Income generating activities } \\
\text { Humanitarian assistance from international }\end{array}$ & 3.44 & 72.085 & 0.805 & 33.85 & .006 & $4.20 \%$ & $3.50 \%$ & $39.90 \%$ & $47.6 \%$ & $3.90 \%$ \\
\hline $\begin{array}{l}\text { stakeholders }\end{array}$ & 2.69 & 34.145 & 1.331 & 22.327 & .323 & $2.80 \%$ & $38.50 \%$ & $51.40 \%$ & $4.90 \%$ & $1.10 \%$ \\
\hline loan from local business & 2.46 & 51.578 & 0.803 & 23.963 & .090 & $11.10 \%$ & $39.20 \%$ & $40.30 \%$ & $7.30 \%$ & $0.30 \%$ \\
\hline Relief fund & 2.42 & 46.233 & 0.883 & 25.536 & .061 & $14.60 \%$ & $39.90 \%$ & $33.30 \%$ & $10.8 \%$ & $0.30 \%$ \\
\hline Temporary employment & 2.81 & 54.597 & 0.866 & 16.419 & .424 & $9.40 \%$ & $19.40 \%$ & $51.40 \%$ & $17.7 \%$ & $0.70 \%$ \\
\hline $\begin{array}{l}\text { Access to resources and beneficiary's } \\
\text { satisfaction (Constant) }\end{array}$ & & & & & & V D & $\mathrm{D}$ & NSND & $\mathrm{S}$ & V S \\
\hline Cyclone resilient & 1.25 & 35.651 & 0.59 & 76.591 & .000 & $80.90 \%$ & $13.30 \%$ & $3.80 \%$ & $0.70 \%$ & $0.30 \%$ \\
\hline Safety & 1.35 & 37.402 & 0.608 & 104.022 & .000 & $70.40 \%$ & $25.30 \%$ & $2.80 \%$ & $0.70 \%$ & $0.40 \%$ \\
\hline Cost-efficiency & 1.28 & 42.806 & 0.502 & 117.076 & .090 & $72.90 \%$ & $22.60 \%$ & $2.40 \%$ & - & - \\
\hline Use of technology & 1.25 & 43.87 & 0.48 & 87.084 & .000 & $76.00 \%$ & $20.50 \%$ & $2.10 \%$ & - & - \\
\hline Giving importance to culture & 1.20 & 43.904 & 0.462 & 109.961 & .000 & $82 \%$ & $15.50 \%$ & $2.50 \%$ & - & - \\
\hline Sustainability & 1.27 & 28.33 & 0.751 & 107.835 & .000 & $77.80 \%$ & $17.70 \%$ & $2.40 \%$ & $0.30 \%$ & - \\
\hline Community participation & 1.24 & 40.853 & 0.509 & 91.652 & .000 & $78.80 \%$ & $15.60 \%$ & $3.80 \%$ & - & - \\
\hline Coping and adapting capacity & 1.21 & 40.207 & 0.508 & 96.079 & .000 & $82.30 \%$ & $12.80 \%$ & $3.50 \%$ & $0.30 \%$ & \\
\hline
\end{tabular}

Notes: Note: Scale ranges from $1=$ very low to $5=$ very high and from $1=$ very dissatisfied to very satisfied. The null hypothesis is $H_{0}: \mu=\mu o$ and alternative hypothesis is $H_{1:} \mu>\mu_{0}$, where $\mu$ represents the mean for population, $\mu_{0}$ is the critical rating at 3 . The level of significance of one-tailed test is 0.05. VD = very dissatisfied, $D=$ dissatisfied, $N S N D=$ neither satisfied nor dissatisfied, $S=$ satisfied, and VS= very satisfied.

Table 4: Respondent's safety and security in the reconstructed house

\begin{tabular}{|l|l|l|l|l|l|l|l|l|l|l|}
\hline & Mean & T-value & SD & $\begin{array}{l}\text { Chi- } \\
\text { square }\end{array}$ & $\begin{array}{l}\text { P- } \\
\text { value }\end{array}$ & $\begin{array}{l}\text { very } \\
\text { low }\end{array}$ & low & $\begin{array}{l}\text { mode } \\
\text { rate }\end{array}$ & $\begin{array}{l}\text { hig } \\
\text { h }\end{array}$ & $\begin{array}{l}\text { Very } \\
\text { high }\end{array}$ \\
\hline $\begin{array}{l}\text { High modern } \\
\text { design }\end{array}$ & 1.11 & 42.486 & .374 & 41.520 & .000 & $\begin{array}{l}64.2 \\
\%\end{array}$ & $5.2 \%$ & $1.4 \%$ & - & - \\
\hline $\begin{array}{l}\text { Technological } \\
\text { use }\end{array}$ & 1.13 & 41.418 & .389 & 51.626 & .000 & $\begin{array}{l}63.2 \\
\%\end{array}$ & $6.3 \%$ & $1.4 \%$ & - & - \\
\hline $\begin{array}{l}\text { Hazard - } \\
\text { resistance }\end{array}$ & 1.24 & 31.627 & .559 & 81.596 & .000 & $\begin{array}{l}57.6 \\
\%\end{array}$ & $9.0 \%$ & $3.5 \%$ & - & - \\
\hline
\end{tabular}




\begin{tabular}{|l|l|l|l|l|l|l|l|l|l|l|}
\hline $\begin{array}{l}\text { structures and } \\
\text { retrofitting }\end{array}$ & & & & & & & & & & \\
\hline $\begin{array}{l}\text { Resilience to } \\
\text { hazard }\end{array}$ & 1.18 & 33.901 & .498 & 89.480 & .000 & $\begin{array}{l}61.5 \\
\%\end{array}$ & $5 . \% 9$ & $3.5 \%$ & - & - \\
\hline
\end{tabular}

Table 5: Regression analysis of resourcing for housing reconstruction

\begin{tabular}{|c|c|c|c|c|}
\hline Variables & $\begin{array}{c}\text { Std } \\
\text { error }\end{array}$ & $\begin{array}{c}\text { Beta } \\
\text { Coefficient }\end{array}$ & $\begin{array}{c}\mathrm{T}- \\
\text { value }\end{array}$ & $\begin{array}{c}\mathrm{P}- \\
\text { value }\end{array}$ \\
\hline \multicolumn{5}{|l|}{ Reconstruction (Constant) } \\
\hline Age & 0.002 & 0.018 & 0.299 & 0.766 \\
\hline Gender & 0.068 & -0.175 & -2.93 & 0.004 \\
\hline Monthly income & 0 & 0.021 & 0.295 & 0.769 \\
\hline Marital status & 0.087 & -0.02 & -0.335 & 0.738 \\
\hline Level of education & 0.04 & 0.012 & 0.17 & 0.865 \\
\hline Level of access to land & 0.05 & -0.066 & -1.038 & 0.3 \\
\hline Access to resources & 0.161 & 0.142 & 1.998 & 0.047 \\
\hline Income generating activities & 0.034 & -0.004 & -0.068 & 0.946 \\
\hline Level of access to the quality of building materials & 0.055 & -0.056 & -0.807 & 0.42 \\
\hline Level of access to construction expertise & 0.061 & 0.154 & 2.301 & 0.022 \\
\hline Level of access to technological innovation & 0.048 & -0.197 & -2.783 & 0.006 \\
\hline \multicolumn{5}{|l|}{ Vulnerability reduction (Constant) } \\
\hline Age & 0.002 & 0.07 & 1.305 & 0.193 \\
\hline Gender & 0.068 & 0.045 & 0.819 & 0.414 \\
\hline Monthly income & 0 & 0.119 & 1.808 & 0.072 \\
\hline Marital status & 0.086 & -0.041 & -0.749 & 0.455 \\
\hline Level of education & 0.04 & 0.087 & 1.331 & 0.184 \\
\hline Level of access to land & 0.05 & -0.022 & -0.388 & 0.699 \\
\hline Access to resources & 0.161 & 0.25 & 3.872 & 0.00 \\
\hline Income generating activities & 0.034 & -0.061 & -1.132 & 0.259 \\
\hline Level of access to the quality of building materials & 0.054 & 0.112 & 1.763 & 0.079 \\
\hline Level of access to construction expertise & 0.06 & 0.065 & 1.075 & 0.283 \\
\hline Level of access to technological innovation & 0.048 & 0.11 & 1.707 & 0.089 \\
\hline \multicolumn{5}{|l|}{ Quality of reconstructed houses (Constant) } \\
\hline Age & 0.003 & -0.02 & -0.317 & 0.752 \\
\hline Gender & 0.097 & 0.038 & 0.611 & 0.542 \\
\hline Monthly income & 0 & -0.028 & -0.356 & 0.722 \\
\hline Marital status & 0.147 & -0.031 & -0.496 & 0.62 \\
\hline Level of education & 0.048 & -0.076 & -0.997 & 0.32 \\
\hline Level of access to land & 0.064 & -0.018 & -0.268 & 0.789 \\
\hline Access to resources & 0.221 & 0.313 & 3.618 & 0.00 \\
\hline Income generating activities & 0.044 & -0.01 & -0.164 & 0.87 \\
\hline Level of access to the quality of building materials & 0.07 & 0.174 & 2.321 & 0.021 \\
\hline Level of access to construction expertise & 0.077 & 0.258 & 3.389 & 0.001 \\
\hline Level of access to technological innovation & 0.073 & 0.012 & 0.155 & 0.877 \\
\hline \multicolumn{5}{|l|}{ Beneficiary's satisfaction (Constant) } \\
\hline Age & 0.001 & -0.013 & -0.266 & 0.791 \\
\hline Gender & 0.046 & -0.054 & -1.12 & 0.264 \\
\hline Monthly income & 0 & 0.066 & 1.117 & 0.265 \\
\hline Marital status & 0.059 & 0.013 & 0.263 & 0.793 \\
\hline Level of education & 0.027 & 0.079 & 1.134 & 0.18 \\
\hline Level of access to land & 0.034 & 0.038 & 0.743 & 0.458 \\
\hline Access to resources & 0.11 & 0.411 & 7.14 & 0.00 \\
\hline Income generating activities & 0.023 & 0.023 & 0.479 & 0.632 \\
\hline Level of access to the quality of building materials & 0.037 & 0.053 & 0.929 & 0.354 \\
\hline Level of access to construction expertise & 0.041 & 0.151 & 2.781 & 0.006 \\
\hline Level of access to technological innovation & 0.032 & 0.082 & 1.418 & 0.157 \\
\hline \multicolumn{5}{|l|}{ Livelihood recovery (Constant) } \\
\hline Age & 0.002 & 0.015 & 0.287 & 0.774 \\
\hline Gender & 0.065 & 0.036 & 0.664 & 0.507 \\
\hline Monthly income & 0 & 0.085 & 1.299 & 0.195 \\
\hline Marital status & 0.083 & -0.038 & -0.708 & 0.48 \\
\hline Level of education & 0.039 & -0.018 & -0.274 & 0.784 \\
\hline Level of access to land & 0.047 & 0.053 & 0.928 & 0.354 \\
\hline Access to resources & 0.154 & 0.153 & 2.401 & 0.017 \\
\hline
\end{tabular}


Income generating activities

\begin{tabular}{llll}
0.032 & -0.069 & -1.297 & 0.196 \\
0.052 & 0.208 & 3.317 & 0.001 \\
0.058 & 0.196 & 3.271 & 0.001 \\
0.046 & 0.087 & 1.371 & 0.172 \\
\hline
\end{tabular}

Level of access to the quality of building materials

Level of access to construction expertise

0.046

0.087

Model statistics

\begin{tabular}{lcccccc}
\hline & Reconstruction & VR & QRH & $\begin{array}{c}\text { Livelihood } \\
\text { recovery }\end{array}$ & $\begin{array}{c}\text { B. } \\
\text { satisfaction }\end{array}$ & $\begin{array}{c}\text { Poverty } \\
\text { reduction }\end{array}$ \\
\hline Sample size & 285 & 285 & 285 & 285 & 285 & 285 \\
Significance & .000 & .001 & .000 & 0.013 & .000 & .000 \\
Adjusted R square & 0.085 & 0.067 & 0.285 & 0.046 & 0.398 & 0.261 \\
\hline
\end{tabular}

Notes: VR = Vulnerability Reduction, QRH = Quality of Reconstructed Houses, B.satisfaction =

Beneficiary's satisfaction.

Table 6: The result of the t-test and frequency distribution of acute poverty, safety and cyclone resilient houses

\begin{tabular}{|c|c|c|c|c|c|c|c|c|c|c|c|}
\hline SLno & & $\begin{array}{l}\text { Very } \\
\text { dissatisfi } \\
\text { ed }\end{array}$ & $\begin{array}{l}\text { dissatisfi } \\
\text { ed }\end{array}$ & $\begin{array}{l}\text { Neither } \\
\text { satisfied } \\
\text { nor } \\
\text { dissatisfi } \\
\text { ed }\end{array}$ & satisfied & $\begin{array}{l}\text { Very } \\
\text { satisfied }\end{array}$ & $\begin{array}{l}\text { Very } \\
\text { low }\end{array}$ & low & $\begin{array}{l}\text { Mode- } \\
\text { rate }\end{array}$ & high & $\begin{array}{l}\text { Very } \\
\text { high }\end{array}$ \\
\hline 1 & $\begin{array}{l}\text { Acute } \\
\text { poverty }\end{array}$ & - & - & - & - & - & $3.9 \%$ & $2.8 \%$ & $6.7 \%$ & $45.8 \%$ & $40.8 \%$ \\
\hline 2 & $\begin{array}{l}\text { Cyclone } \\
\text { resilient }\end{array}$ & $81.8 \%$ & $13.3 \%$ & $3.9 \%$ & $.7 \%$ & $.4 \%$ & & & & - & - \\
\hline 3 & Safety & $70.2 \%$ & $25.6 \%$ & $2.8 \%$ & $.7 \%$ & $.4 \%$ & - & - & & - & - \\
\hline
\end{tabular}

Table 7. Hierarchical Regression Analysis of socio-economic factors and access to resources

\begin{tabular}{|c|c|c|c|c|c|c|c|c|c|c|c|}
\hline Model & Variable & $\begin{array}{c}\text { Adjusted } \\
\mathrm{R}^{2} \\
\end{array}$ & $\begin{array}{c}\mathrm{R}^{2} \\
\text { Change } \\
\end{array}$ & $\begin{array}{c}\mathrm{F} \\
\text { change }\end{array}$ & $\begin{array}{c}\text { U. } \\
\text { Coeff } \\
\end{array}$ & $\begin{array}{c}\text { S. } \\
\text { Coeff } \\
\end{array}$ & $\begin{array}{c}\mathrm{T} \\
\text { value }\end{array}$ & $\mathrm{DF} 1$ & $\mathrm{DF} 2$ & $\begin{array}{c}\text { Sig.F } \\
\text { change }\end{array}$ & $\begin{array}{c}\mathrm{P} \\
\text { value }\end{array}$ \\
\hline \multirow[t]{8}{*}{1} & Step 1 & .055 & .072 & 4.234 & & & & 5 & 272 & 0.001 & \\
\hline & Age of the respondents & & & & $0.004^{-}$ & 0.078 & $1.309^{-}$ & & & & .192 \\
\hline & Gender of the & & & & & & & & & & \\
\hline & respondents & & & & 0.319 & 0.227 & 3.755 & & & & $.000 *$ \\
\hline & & & & & $0155^{-}$ & 0085 & $1412^{-}$ & & & & \\
\hline & Marital status & & & & 0.152 & 0.085 & 1.412 & & & & .159 \\
\hline & Monthly income & & & & 0.069 & 0.102 & 1.388 & & & & .145 \\
\hline & Level of education & & & & 1.979 & 0.099 & 1.461 & & & & .145 \\
\hline \multirow[t]{6}{*}{2} & Step 2 & .106 & .066 & 4.115 & & & & 5 & 267 & 0.001 & \\
\hline & Age of the respondents & & & & 0.004 & 0.083 & $1.411^{-}$ & & & & 0.159 \\
\hline & Gender of the & & & & - & - & - & & & & \\
\hline & respondents & & & & 0.261 & 0.186 & 3.061 & & & & $.002 *$ \\
\hline & Marital status & & & & 0.083 & 0.046 & -0.77 & & & & .442 \\
\hline & Monthly income & & & & 1.904 & 0.096 & 1.353 & & & & .177 \\
\hline
\end{tabular}


Level of education

Access to resource

Access to land

Access to institutional

resources

Access to community

resources

Access to building materials

3 Step 3

Age of the respondents

Gender of the

respondents

Marital status

Monthly income

Level of education

Access to resource

Access to land

Access to institutional

resources

Access to community

resources

Access to building

materials

Income generating

activities

Access to technological

application

Access to financial

resources

Access to construction

specialists

Access to human

resources $\begin{array}{lll}0.052 & 0.077 & 1.067\end{array}$

$\begin{array}{lll}0.486 & 0.174 & 2.521\end{array}$

$.012 *$

$\begin{array}{lll}0.078 & -0.08 & 1.239\end{array}$

.216

$0.149 \quad 0.185 \quad 2.583$

$.001^{*}$

$\begin{array}{lll}0.102 & 0.111 & -1.54\end{array}$

.125

$\begin{array}{lll}0.136 & 0.14 & 1.87\end{array}$

.063

$\begin{array}{lll}5 & 262 & .029\end{array}$

$\begin{array}{lll}0.003 & 0.073 & 1.254\end{array}$

.211

$\begin{array}{lll}0.235 & 0.167 & 2.761\end{array}$

$.006^{*}$

$\begin{array}{lll}0.042 & 0.023 & 0.389\end{array}$

.697

$2.245 \quad 0.113 \quad 1.566$

.119

$\begin{array}{lll}0.03 & 0.045 & 0.62\end{array}$

.536

$\begin{array}{lll}0.418 & 0.149 & 2.077\end{array}$

$.039 *$

$\begin{array}{lll}0.062 & 0.064 & 0.979\end{array}$

.328

$\begin{array}{lll}0.105 & -0.13 & 1.595\end{array}$

.112

$\begin{array}{lll}0.145 & 0.158 & 2.112\end{array}$

$.036 *$

$\begin{array}{lll}0.129 & 0.133 & 1.694\end{array}$

.091

$\begin{array}{lll}0.072 & 0.102 & 1.723\end{array}$

$.016^{*}$

$\begin{array}{lll}0.079 & 0.095 & 1.215\end{array}$

.225

$\begin{array}{lll}0.074 & 0.07 & 0.943\end{array}$

.346

$\begin{array}{lll}0.177 & 0.158 & 2.323\end{array}$

$.021 *$

$0.036 \quad 0.046 \quad 0.535$

Notes: $* *$ Significant at $\mathrm{p}<0.01$, U.Coeff $=$ Unstandardized Coefficient and S.Coeff $=$ Standardized Coefficient. 